\title{
2. SOCIO ECONOMIC IMPACT OF UNDECLARED BLOCKADE OF INDIA ON NEPAL
}

- Bhuwaneswor Pant ${ }^{2}$

\begin{abstract}
Indian unofficial or undeclared blocked was a terrible move. It was a move on the part of Indian diplomacy. India imposed it, it was very transparent but not acceptable. Diplomacy is getting thing done without speaking or telling nastiest words in nicest manner. What had happened in southern border of Nepal? What was Indian's role? The study attempts to find out the reason of undeclared blocked of 2015 and identify the socio economic impact of this blocked imposed during the dark days of great earthquake in Nepal. Can a neighbor do so? India did it but did not speak a single word. The study has been conducted to analyze the impacts of the issue. Library method and comparative review methods were applied to analyze the impacts it had on Nepal. They tried to minimize the Chinese Communists influences but the move was wrong. So, Nepalese citizens cast their vote to elect communist parties with full majority. Indian policy was concentrated on causing instability in Nepal. Nepalese diplomacy proved to be ineffective to put pressure on Indian government for amending the Sugauli Treaty and the Treaty of 1950 as well as addressing controversy over Kalapani, Susta and Lipulek. At the time of election, all the political parties raised the issue against India as KP Oli did and successfully won the election. The pain of blockade is not forgotten in the name of improving bilateral relations.
\end{abstract}

Key words: Nepal India Relations, Socioeconomic Impacts, blockade

\section{Introduction}

The socio economic impact is the study of causes and consequences of a phenomenon that directly or indirectly affects the human life. The phenomena or related issues of a particular event happens everyday life. Rain falls so what it increases the agricultural productivity in the meantime it may occur a big flood that havocs many lives. The cause is simply the rain and the consequences are productivity as well as the devastating flood. A cause produces either positive or negative impact in society. The rain is good most of the time but bad in some time. If it is good its consequential impact in society will be positive and vice versa. Impacts are potential changes caused - directly or indirectly, in whole or in part, for better or for worse- by different activities. Socio-Economic Impact analysis is often a component of Environmental Impact Statements (EIS) for major development projects. Socio-economic impacts studies include: qualitative community impacts such as project educational and quality of life benefits; project competitive impacts; and the impacts considered in EIS such as population, demographics, land use and economy. However, the case on this study is political and diplomatic.

The unofficial blockade which began around September 2015 has led to a severe humanitarian crisis here in Nepal. Traditionally a blockade was a method of economic warfare as it affected

2 Mr. Panta is a PhD scholar and involved in teaching 
the relations between blockaded belligerent and neutrals. It was one of the tools employed by neutral countries to maintain their neutrality (INHURED, 2016). Post 19th century there have been very few practices of economic blockades, and most of them are directed against military operations and armed forces instead of the economy. But in the present Nepalese context, blockade is being used as an underhanded tool for continuing the rebellion by the "Madhesis' and as way of controlling the economy by the Indian Government. Hence, the present blockade can be analyzed as a two pronged attacks on the economy; 1st the border blockade done by the agitating parties here in Nepal ; and 2nd the 3 Indian Government withholding necessary supplies like fuel (INHURED, 2016).

Nepal is a central commercial point of India and china. Nepal is attracting the world from Mt. Everest - the head of the world, and watching the world with full of love and compassion from Lumbini - Buddha's Eye. Both India and China are enjoying its natural beauty and cultural philosophy of Buddhism and Hinduism, however it is secular democratic republic country surrounded three sides by India and one side from China.

As Nepal has $80 \%$ Hindus and $10 \%$ Buddhists Nepal is very close to India from socio cultural perspective, on the other hand China is very far from geographically, linguistically and Tibet issue. Many communist leaders want to attract China in mainstream as India is in, but China is indifferent in internal issues. Nepal is a safe buffer zone for both of them. India's influence is very high in Nepal and China feels unsecure with Nepalese diplomacy. Ironically India is very close to Nepal from social, cultural, geographical, political and linguistic perspective but it has imposed blocked many times. India has imposed border blockade at four times $(2019,2027,2045$, and 2072 ) in the history causing crisis in bilateral relationship. The close alley is kicking the goal. India's diplomacy to Nepal shows the influence of game theory and conspiracy theory to win the blocked game. Nepal has got the point but it is not able to convince the consequences to China. India did it but still not accepting it.

United Nations - On 11 November, Secretary-General Ban Ki-Moon reiterated his "concern over the obstruction of essential supplies on the Nepal-India border. Acute shortages in fuel supplies continue to impede planned deliveries to earthquake-affected villages in Nepal," said spokesman Stephane Dujarric. "The Secretary-General underlines Nepal's right of free transit, as a landlocked nation as well as for humanitarian reasons, and calls on all sides to lift the obstructions without further delay." Similarly, Bangladesh - On 18 October, Tofail Ahmed, Minister of Commerce, Bangladesh, a supporter of India's South Asia trade policies, urged an end to the blockade and commented that such blockades hit at agreements like the BBIN.

European Union - On 24 October, Jean Lambert, MEP and Chair of the European Parliament Delegation to South Asia, stated the unofficial 'blockade' at the Nepali border only serves to hurt the Nepali people who are still recovering from the devastating earthquakes earlier this year.

The economic growth outlook, which was getting weakened on account of strike in the Southern parts of the country since the first month of the current fiscal year, further deteriorated owing 
to unofficial economic blockade imposed by India. The blockade on the import of essential commodities such as medicines, food grains and petroleum products has made public life miserable. So is the case of developmental projects which remain stalled on account of shortage of fuel and necessary raw materials (NRB, 2016).

According to a report carried by The Indian Express on 23rd September 2015, India proposed a seven-point amendment to Nepal's Constitution to resolve the ongoing unrest in Terai/Madhes. These amendments were almost similar to the demands of the Madhesi front. The Indian Ministry of External Affairs (IMEA) refuted the media report, saying that it did not propose any amendment. However, The Indian Express stood by its report that India communicated these amendments/ changes conveyed to the Government of Nepal (MASUM, 2016).

Due to the disruption, the lives of the people of Nepal have become miserable. School students, college students and office goers have not been able to reach their destinations due to paucity of public transports, which is not operating regular services due to non-availability of fuels. Patients do not get medical care due to scarcity of medicine. People residing nearby Panitanki can arrange their daily requirements, though at a higher cost. But the people in the remotest part of Jhapa district and other adjoining districts are in acute distress. There were no reported incidents of violence or political protests in this part of Nepal. Why the administration of the Indian Government took the stand to either halt or slow down the movement of vehicles is a real mystery for the Nepali authorities (MASUM, 2016).

\section{Objectives/ Methodology/ Review}

The objective of the study is to find out the reason of undeclared blocked of 2015 and to identify the socio economic impact of this blocked on the cold days of great earthquake in Nepal. India did it but did not speak a single word. To analyze the impacts of the issue the study has been conducted.

Library Method: the study has been conducted through the library method reviewing the wide range of research, articles and reports.

Comparative Review Method: comparative review method is the method of comparing reviews. Different reviews are compared from Indian and Nepali sides to analyze the socioeconomic impacts of unofficial blocked.

\section{Discussion}

\section{a. Chronology of Blockade}

The 1970 Blockade: In 1970, a dissatisfied India obstructed the movement of goods into Nepal after the latter built the Araniko Highway linking Kathmandu with China, and opened Tatopani as a trade route with the northern neighbor. Even though the economic blockade of 1970 was for the short period of time, it had created a problem in smooth supply of some commodities like 
salt, spices products in the country as Nepal was dependent for these products on India (Subedi, 2016). The first obstruction occurred during 1969 after the expiration of the 1950 Trade and Transit Treaty; where the Indian government imposed quantitative restrictions on cross border transactions. The extent, to which Nepal's economy was affected, is however unclear given the lack of quantitative figures during the time-period. Nonetheless, the impact on the economy was not as pronounced as the current situation given the brief duration of the blockade, adequate food production with net exports in agriculture, and minimal consumption of petroleum products; due to a fewer number of transport vehicles, prevalent traditional methods of wood-fire cooking and fewer number and degree of institutions (such as banks, schools, and various other service companies) and interlink-age between them (Shakya \& Bhattarai, 2016).

The 1989 Blockade: On the pretext of buying a batch of Chinese Weapons, The Indian blockade which started from April 1989 lasted for about 15 months had created shortages of essential commodities like food products, salt, oil, spices including the supply of petroleum products (Subedi, 2016). The 1989 blockade also emerged following the expiration of the trade and transit treaties, which by this point had been separated into two different treaties i.e. Treaty of Trade and Treaty of Transit. The geopolitics surrounding the impasse spanned over decades with multiple instances of friction especially observable after 1975. During early to mid-seventies several notable events occurred including Late King Birendra's ascendency to the throne, partition of Pakistan and annexation of Sikkim. Following these events, a proposition was made to declare Nepal as a "Zone of Peace" which India refused (Shakya \& Bhattarai, 2016).

This Economic Blockade was an extreme inhuman practice which India will regret sooner or later. The fundamental rights of Indian as well as Nepali people were violated and the interesting thing is Judicial Action has not been taken till date. This kind of practice by India time and again questions the existence of India as a good neighbor. This blockade has made the people of Nepal think that Nepal is India locked rather than Landlocked (Subedi, 2016).

\section{b. Socio-economic Impacts}

There was a four-month long blockade on the Indo-Nepal border that began immediately after Nepal adopted a new Constitution on September 20, 2015. The blockade was along Nepal's southern border with India, covering the Madhes or Terai region. The flow of goods and fuel to Nepal was choked at border check points. This resulted in one of the worst humanitarian and geo-political crisis in the region as fuel, medicines and other essential items of daily life could not reach Nepal from India (SAHR, 2016). It has seriously increased the anti-Indian sentiment in Nepal. The blockade was an extreme form of protest with complex consequences, including grievous harm to the weakest and poorest sections of Nepali society and alienating communities the protestors should have been making common cause with. Yet, judging it a failure as a tactic should not substitute for a careful assessment of what is in effect a social movement in the Tarai (ICG, 2016). It is not the issue of Tarai but it is the issue of politics.

Education: The continuous blockade by India has directly hit the entire academic sector, compelling 
shutdown of schools. The fuel crisis has affected millions of students, including around one million school students in the Valley alone. As informed by Lachhe Bahadur KC, President of Private and Boarding Schools' Organization Nepal, of the 2000 private schools operating in the Kathmandu Valley, about 80 per cent have been closed as they faced difficulty to ferry students and teachers to and from schools. UNICEF estimates that more than 1.6 million children in the nine districts in the central and eastern plains alone have been deprived of schooling following the unrest in the Terai as schools in Terai have been forced to remain shut for the last 75 days (INSEC $\&$ DFHRI, 2016). The demonstration, band, strikes etc. have negative psychological impacts with children and youths.

Health: Health sector is another major sector hit by the blockade. Hospitals are gradually being unable to provide health care services due to the shortage of oxygen, medicines and blood supply. The hospital authorities have made it clear that they are not in a position to run hospitals without those vital supplies. They also highlighted that the dispensaries will not be able to supply lifesaving medicines in future if the on-going economic blockade persists any longer. Major public hospitals in the Kathmandu Valley including Bir Hospital, Teaching Hospital, Kanti Children Hospital, Patan Hospital, Civil Service Hospital, Gangalal National Heart Centre and Paropakar Maternity and Women Hospital need 1700 litres of diesel, 200 litres of petrol, 18 cylinders of LPG and 245 cylinders of oxygen every day to run their services unhindered (INSEC \& DFHRI, 2016). Most of the patients have to suffer more than others. Those patients are the agent of anti-Indian sentiments.

Transportation: The blockade has disrupted transportation at the height of Nepal's national holiday season, preventing millions from travelling to ancestral homes. There have been many deaths from traffic accidents caused by dangerously overcrowded public transport, with passengers including women, children and the elderly forced to travel precariously on rooftops of buses. On the other hand, according to the National Federation of Transport Entrepreneurs, the transport sector is facing a loss of 200 to 250 million rupees a day (INSEC \& DFHRI, 2016). The business was in serious condition.

Energy: Nepal needs 1200 megawatt electricity to meet its energy requirements. But, current production of hydroelectricity in Nepal is only 600 megawatts and 180 megawatts is imported from India. Rest of the energy need is met using generators. The shortage of fuel supply has badly affected the operation of generators causing huge energy crisis. Similarly, the LPG crisis has caused huge difficulty for the Kathmandu Valley consumers to prepare their meal. Most of the hotels and restaurants have been forced to shut. Country's monthly LPG demand stands at 32,000 tones, which soars 30-40 per cent during winter. However, the Indian Oil Corporation has sharply cut the supply of LPG to Nepal since the unofficial trade and transit embargo. According to the Nepal Oil Corporation, more than 225 gas bullets have been stuck on the Indian side of the border. A bullet carries 18 tons of LPG (INSEC \& DFHRI, 2016). The shortage of energy has paralyzed the lives in Kathmandu. Kathmanduities cannot forget the pain easily that has hampered the diplomacy. 
Food: Acute shortage of fuel continues to impede planned deliveries of relief supplies to the earthquake-affected villages. According to the United Nations Humanitarian Coordinator's Office in Kathmandu, hundreds of tons of food materials meant for the earthquake victims are stuck in warehouses. Not only the earthquake-affected villages, many other food insecure villages of the country are facing food scarcity due to the limited supply. There is possibility of a mass hunger in the near future. In the areas, where foods are still available, prices of food items have gone exceptionally up reaching beyond affordable capacity of general people (INSEC \& DFHRI, 2016).

Agriculture: Over 70 percent of Nepal's population works in the agriculture sector, accounting for 38 percent of the GDP. Due to the blockade, farmers are not getting improved seeds and fertilizers that are largely imported from India and other countries. Imported fertilizers are currently dumped in Indian border owing to transit blockade by India. In addition, in most of the Terai region considered to be the Nepal's food basket, water supply for the irrigation is done by pumping water. Farmers of the region are complaining that they have not been able to cultivate their lands owing to the lack of fuel to operate water pumps and irrigate their fields. It is going to significantly reduce the food production in the region and ultimately create food scarcity in the country (INSEC \& DFHRI, 2016).

Economy and development: All over Nepal, industries as well as small businesses are closed and development activities, including construction of vital infrastructure, are at standstill. Tourism has been severely disrupted during what would have been a peak season. Employment prospects have diminished nationally, forcing hundreds of thousands more to consider migrating to India, the Gulf and Malaysia. The government's collection of revenue and its expenditure have both declined as of October 23 of the current fiscal year due to the long-running banda (general strike) in Terai and unofficial embargo imposed by India. According to the Nepal Rastra Bank (NRB), the government collected only Rs 77 billion in revenues as compared to Rs 90 billion in the same period last fiscal year (INSEC \& DFHRI, 2016). The year 2015 was not a particularly good year for tourism and its adjoining businesses. While tourist arrivals dwindled after the April earthquake, the emerging signs of recovery in subsequent months were soon dampened by the Madhes agitation. As a result, number of tourists fell to a six-year low in 2015 at 538,970 (Shakya \& Bhattarai, 2016).

Likewise, the private sector business is losing around Rs. 2 billion daily due to the Banda and blockade. The Federation of Nepalese Chambers of Commerce and Industry (FNCCI) and Nepal Chambers of Commerce (NCC) have warned that the industrial sector would face a disaster if the government did not announce relief package for the business sector (INSEC \& DFHRI, 2016).

The country faced a trying year in 2015, first with the earthquake - which dealt a devastating blow to the economy, and further compounded by the blockade. Apart from inflicting great economic and social costs to the country, the blockade led to a state of humanitarian crisis wherein the crippling shortage of fuel and other essentials made lives across the country extremely difficult (Shakya \& Bhattarai, 2016). This had a multi-faceted impact on the country; especially in terms of 
day to day livelihoods, transportation and across sectors particularly agriculture, manufacturing, trade and business, health, education and tourism. Failure to transport winterization kits hampered rehabilitation of earthquake victims who had to face the winter under shortage of fuel and warm clothes. As such, those affected by the earthquakes became double victims, i.e. of both natural and man-made calamities (Shakya \& Bhattarai, 2016). The blockade pushed hundreds of thousands of people below the poverty line, over and above those already pushed below the line by the earthquakes. It also jeopardized the livelihoods of many, which are likely to have long term impacts in terms of productivity. While on the one hand, the country is vulnerable to external shocks like the blockade, on the other hand, it lacks the capability and economic vitality to cope with multiple natural disasters. Given such a scenario, Nepal's focus should be on having safety nets in place in order to salvage the economy should such instances threaten the stability of the economy and by extension, the society at large. Both, prevention and better management of such crises require bold pragmatic actions which transcends politics and partisan interests (Shakya \& Bhattarai, 2016).

\section{c. Undeclared Blockade}

India wanted the Madhesis who have age-old affinities and relationship with India and carry old grievances of being ignored by the dominant Nepalese of hill origin, to have a larger sociopolitical space under the new Constitution. This raised the apprehensions once again about India's intimidating and imposing Big Brother approach to its neighbors (SAHR, 2016). The South Asian Association of Regional Cooperation (SAARC) does not, unfortunately and tellingly, have a mechanism to resolve disputes in the region. The Madhesi-centric political parties in Nepal, together with the groups/parties representing the Janjatis, and many marginalized and minority communities had been agitating for proportional representation under the new Constitution and even autonomy for the province. More than 40 people were killed during the agitation last year (SAHR, 2016). The Madhesis have cultural and geographical linkages across the border in Indian states of Bihar and Uttar Pradesh. India has always attempted to play a role, even intervene, in the socio-political developments in Nepal over the years but this time it sought to influence the making of the Constitution itself which was the privilege of the people of Nepal. It rode on the back of the Madhesi agitation causing commentators to call it "mean".

Besides the humanitarian crisis, the blockade also meant that Nepal sought assistance and longterm investments from its other neighbor China. Traditionally, India and China have shared an uneasy relationship. This further skews the power equation in the region (SAHR, 2016). The geographical setting of Nepal and India are very important in shaping their relations. They share not only a long and open border but also cultural history for a long time. Nepal and India had many modes of their relations like- "Sphere of Indian Influence", "special relationship" later turned into "Equal Relationship with all", then "Big Brother role" later become "Dominating power", "Zone of Peace", "Panchayat Regime". So, despite these closeness and friendly relations they had many irritants also. After a long time, Nepal has achieved political stability, except some issues, on September 20, 2015, to adopt a constitution. Nepal had been hankered for a long time to 
achieve this. Now it is time for Nepal to ponder over the all gamut of relations with India because both of the countries can take advantage of each other as Prime Minister Narendra Modi during his two-day visit to Nepal, on 3-4 August 2014, said about the Nepal's development and promised to take all necessary steps to take the relations into a new height. Now, it is interesting to see that what kind of relationship Nepal will maintain with India with these developments (Patel, 2017).

\section{d. India Nepal Relation}

India-Nepal relations reached their lowest during the last one year, bringing about a state of utter confusion; full of allegations and diversions in multiple ways. It is not for the first time that the relations between the two countries have received a setback. In fact, ever since 1950, India-Nepal relations have had a chequered history despite age old historical, social and cultural linkages, an open border, vital trade and transit links, and a sound foundation of relations in the form of the 1950 Treaty of Peace and Friendship. Sometimes, it is highly puzzling why the two countries have come to strain relations time and again despite such multidimensional bonds between them (Choudhary \& Ghosh, 2016)

This blockade pushed the Nepalese economy reeling from the April 2015 earthquake into further tailspin. Estimates put this loss due to the blockade at Nepali Rupee 200 billion. Nepal's thirdcountry trade was also deeply affected because India has been its transit route. This report draws attention to the issues faced by a landlocked country, and the rights and entitlements it has under various international conventions. India orchestrated the blockade after failing to get its way through diplomatic channels in the making of the Nepali Constitution. For the record, India denied effecting or orchestrating the blockade but its external affairs minister tacitly acknowledged India's role referring to the blockade in 1989-90 as "the first one" implying that the 2015 blockade was the second one (SAHR, 2016).

There is no doubt that India lacks clarity and consistency in its approach towards Nepal. There have been allegations about India being reactive instead of being proactive towards its northern neighbor (Choudhary \& Ghosh, 2016). Many Indian projects have not been completed in time although Nepal has also been responsible for this many a time. But it is also a fact that dragging India into the political bickering of Nepal and laying all blame on it is counterproductive. It is irritating to all those who are sincerely working for the development of Nepal. For them, Nepal's approach is frustrating. However, there are many brighter aspects to the India-Nepal relationship. These aspects need appreciation in order to build a brighter future of the relationship between the two countries (Choudhary \& Ghosh, 2016). The deep rooted socio-cultural linkages that the two countries possess comprise a rare repository in the arena of bilateral relations. But unfortunately, all these and many other aspects of India-Nepal relations are overshadowed by personalized politics and short term gains. For a brighter India-Nepal relationship, Nepal needs stability, development, and a mature political leadership. On the other hand, India needs to follow a clear, consistent, transparent, and more cooperative approach towards a close neighbor (Choudhary \& Ghosh, 2016). New Delhi needs to give continuity to its stand on the Nepalese constitution. It should 
use its leverage to influence Nepalese politicians to accommodate the aspirations of the agitating parties in the constitution by amending it to their satisfaction. It is in Nepal's own interest to amend the constitution in a way that it becomes inclusive. If at all New Delhi has lost any section of society in Nepal in the course of the anti-constitution movement, it is the group of opportunists. Instead, New Delhi has earned credibility from larger sections of Nepalese population, which is not a small gain. In order to consolidate its gain, what is essential for New Delhi is to sideline the forces that indulge in propaganda about Chinese activities in Nepal, including the extension of its railway network deep into the Nepalese territory, being in Nepal's interest. It is clear as mirror that all the Chinese activities in Nepal have a strategic design that would neither serve Nepal's long term interest nor that of India.

The relation between Nepal and India are getting worse and worse because of lack of trust and cooperation. In this regard, both countries did not make any serious attempt to solve this issue besides tall talks. It is India's biggest diplomacy failure that it doesn't minimize its relationship deficit with Nepal. Now, it is necessary to, without tall talks, both countries have to try to give a new direction to their relationship and must make it more and more useful in changing world scenario. Nevertheless, no one can undermine their centuries old cultural and social linkages and geographical setting as well. This is the only reason of their good, and as well as bad, relationship that always helps in maintaining their relationship. In the era of globalization, where each one country has come closer to gain more and more profits while Nepal and India, instead of closeness, do not seem in able to utilize each other's potentials. In this task, India has failed to improve its soft power potentiality while this can be achieved through the little efforts because it has already been working in an undirected and neglected way (Patel, 2017).

\section{Conclusion}

In conclusion the main reason behind the unofficial blocked is to protect pro Indian politicians in Nepal on their demand of whole Tarai as a province which is very dangerous to Nepalese security and sovereignty. It was a diplomatic move where India had refused to accept it as the blockade but it is an unofficial blockade. Modi's diplomacy was failed in Nepal; anti-Indian sentiment was mounted at the time ever in History. The main reasons of unofficial blocked are to rule south Asia as a big brother. It pressurized Nepal government to impose Indian hegemony in Tarai with the help of recently migrated Indians. To minimize the Chinese Communists influences but the move was wrong so Nepal has elected communist government with easy full majority. To develop Hinduism and extremism in Nepal. Indian policy might be concentrated to instability in Nepal because It has always supported weak force against strong forces. Nepalese diplomacy seems weak to put agenda to amend the Sugauli Treaty, Treaty of 1950, issues of Kalapani, Susta and Lipulek in Delhi. At the time of election entire political parties raise the issue against India as KP Oli did and successfully won the election, the pain of blocked is forgotten in the name of improving bilateral relations. India has not taken the issue seriously because socio economic impact on Health, Education, Transportation, Energy, Fuel, business and economy were devastated, the earthquake had killed 10,000 people millions were injured but India played the game through 
conspiracy theory. Leaders will forget but people will never forget it so India has to apologize for the inhuman behavior and must welcome Nepalese constitution 2015.

\section{References}

Choudhary, N., \& Ghosh, A. (2016). Indo-Nepal economic cooperation: A subregional perspective. Delhi: Indian Foreign Affairs Journal Vol. 11, No. 2, April-June 2016, 93-123.

ICG (2016). Nepal's divisive new constitution: An existential crisis. Brusels: International Crisis Group Asia Report No 276, 4 April .

INHURED (2016). Unofficial blockade of Nepal by India :Issue Brief. Kathmandu : INHURED INTERNATIONAL .

INSEC \& DFHRI (2016). Unilateral coercive blockade imposed by India on Nepal. Kathmandu: www.insec.org.np and www.dfhri.org.

MASUM (2016). Report on fact-finding on impact of blockade along Indo-Nepal border. Kathmandu/ Dhaka: Banglar Manabadhikar Suraksha Mancha (MASUM).

NRB (2016). Current macroeconomic and financial Situation of Nepal (Based on Three Months' Data of 2015/16). Kathmanu Nepal: Nepal Rastra Bank Research Department.

Patel, S. ( 2017). A New Journey in the New Context: Nepal-India Relations. IOSR Journal Of Humanities And Social Science (IOSR-JHSS) Vol. 22, Issue 9, Ver. 11, September, 73-79.

SAHR (2016). Nepal Blocked a humanitarian crisis, a midsts diplomatic kerffufle : A fact finding mission report. Colombo: South Asians for Human Rights (SAHR), Shri Lanka.

Shakya, A., \& Bhattarai, T. N. (2016). Post Disaster Assessment: Blockade 2015/16. Kathmandu : Nepal Economic Forum and Allince for Social Dialogue .

Subedi, S. (2016). Academia . Retrieved from, https://www.academia.edu/33773541/

Economic_Blockade_2015.pdf. 